\title{
Diversifikasi Pangan Sumber Karbohidrat Canna edulis Kerr. (Ganyong)
}

\author{
Nita Noriko, Arief Pambudi \\ Program Studi Biologi, Fakultas Sains dan Teknologi \\ Universitas Al Azhar Indonesia, Jl. Sisingamangaraja, Jakarta 12110 \\ Penulis untuk korespondensi/Email: nita_noriko@uai.ac.id
}

\begin{abstract}
Abstrak - Fenomena adanya penyakit akibat kurangnya asupan serat yang memicu penyakit degeneratif di masyarakat perlu mendapat perhatian karena dapat menimbulkan masalah nasional di masa mendatang. Penelitian mengenai kadar serat dan metabolit sekunder Canna edulis Kerr. (Ganyong) yang dilanjutkan dengan pengabdian masyarakat telah dilakukan. Metode yang digunakan dalam penelitian adalah survey sedangkan pengabdian masyarakat berupa edukasi kepada masyarakat mengenai pentingnya serat dan metabolit sekunder melalui diversifikasi pangan sumber karbohidrat non beras seperti Canna edulis Kerr. (Ganyong). Hasil penelitian menunjukkan bahwa serat tertinggi Ganyong terdapat pada daun, selain itu ganyong juga mengandung metrabolit sekunder seperti flavonoid, steroid dan alkaloid. Pengabdian masyarakat dilaksanakan di desa Sindanglengo Gunung Putri Jawa Barat. Penelitian juga menunjukkan bahwa masyarakat telah mengetahui ganyong akan tetapi tidak mengetahui manfaatnya bagi kesehatan. Oleh sebab itu budidaya ganyong kurang dikembangkan oleh masyarakat.
\end{abstract}

Abstract - The phenomenon of disease that caused by lack of fiber intake that induce degenerative disease is important to get attention because it can cause national problem in the future. The research on fiber concentration and secondary metabolic Canna edulis Kerr. (Ganyong) that continued by community serviced were conducted. The methodology used in this research was a survey techniques, whereas community serviced was done through extension to the community about the important of fiber and secondary metabolites through food diversification like Canna edulis Kerr (Ganyong). The research showed that the highest Ganyong fiber found in leaf, leaves also contained secondary metahabolites like flavonoid, steroid and alkaloid. Community serviced was done in desa Sindanglengo Gunung Putri Jawa Barat. This activity indicated that most community has known about Ganyong but they didn't know its benefit for health, which result in lack of Ganyong cultivation.

Keywords - degenerative disease, secondary metabolite, education, food diversification

\section{PENDAHULUAN}

$\mathrm{M}$ asyarakat umumnya memahami malnutrisi sebagai kondisi kekurangan karbohidrat, protein, lemak, vitamin dan mineral. Akan tetapi pemahaman malnutrisi juga mencakup suatu kondisi kelebihan zat gizi seperti karbohidrat khususnya gula. Malnutrisi juga berkaitan dengan kurangnya konsumsi serat yang termasuk gula kompleks. Kelebihan konsumsi gula sederhana akan mendorong metabolism tubuh ke arah biosintesis lemak. Penimbunan lemak dapat memberikan implikasi bagi kesehatan diantaranya adalah diabetes mellitus, konstipasi, hipertensi, dan arterosclerosis.
Pengetahuan ibu tentang gizi tentunya akan mempengaruhi status gizi keluarga. Menurut Hadi, yang melakukan penelitian di SMA Negeri 9 Semarang [1] mengemukakan bahwa telah terjadi perubahan gaya hidup sehari-hari di masyarakat yaitu terjadi penurunan aktifitas fisik dan kelebihan asupan karbohidrat, protein, lemak dan kurangnya konsumsi serat. Dampak dari keadaan ini adalah kelebihan berat badan dan obesitas pada siswa terdapat kecenderungan menyukai makanan cepat saji dan penurunan aktivitas fisik [2]. Kelebihan zat gizi pada remaja cenderung berlanjut hingga dewasa bahkan lansia. Penyakit yang dipicu oleh gizi lebih adalah penyakit degeneratif seperti kardiovaskuler dan diabetes mellitus. 
Canna edulis Kerr yang dikenal dengan tanaman Ganyong merupakan tanaman yang berpotensi mengandung karbohidrat dalam bentuk gula kompleks seperti serat dan kemungkinan juga zatzat metabolik sekunder yang diperlukan untuk kesehatan seperti alkaloid, flavonoid, steroid dan fenolik. Dengan demikian itu diperlukan sosialisasi dalam bentuk pengabdian masyarakat berbasis riset yang tentang tentang manfaat serat dan metabolik sekunder tanaman Ganyong bagi kesehatan.

\section{TINJAUAN PUSTAKA}

Karbohidrat adalah senyawa kimia yang menjadi sumber energi utama (80\%) dari tubuh manusia. Senyawa kimia zat gizi ini terdiri atas Carbon (C), Hidrogen $(\mathrm{H})$, dan $\mathrm{O}$ (Oksigen) dengan rumus kimia $\mathrm{C}_{\mathrm{n}}\left(\mathrm{H}_{2} \mathrm{O}\right)_{\mathrm{n}}$. Orang dewasa dengan aktifitas sedang setiap hari memerlukan karbohidrat sebesar 8 sampai 12 gram $/ \mathrm{Kg}$ berat badan. Konsumsi karbohidrat sebaiknya $70 \%$ adalah gula kompleks yang bersumber dari serat. Kelebihan karbohidrat khususnya gula sederhana dapat memicu kondisi ketosis, yaitu produksi keton oleh hati yang tidak dapat dioksidasi oleh darah. Keadaan ini dapat menyebabkan pembakaran lemak yang berlebihan dengan indikasi peningkatan volume urine, mual, depresi, lelah dan pusing [3]. Karbohidrat yang mengandung gula sederhana yaitu gula yang mudah dimetabolisme menjadi asetil CoA yang selanjutnya memasuki biosintesis lemak. Asupan karbohidrat yang mengandung gula sederhana yang tinggi tanpa diikuti dengan aktifitas fisik akan mempercepat biosintesis lemak. Sumber karbohidrat utama adalah tumbuhan.

Ganyong adalah tanaman herba berumbi dengan kandungan karbohidrat yang lebih tinggi $(88,2 \%)$ dibandingkan umbi-umbian lainnya. Keunggulan tersebut menjadi alasan untuk menjadikan ganyong sebagai pengganti beras dalam rangka diversifikasi pangan. Selain itu, Informasi tentang kandungan metabolit tanaman ganyong masih perlu diteliti [2] [4].

Metabolit sekunder pada tanaman berfungsi sebagai pelindung dari serangan hama. Steroid, flavonoid, alkaloid, dan tanin merupakan senyawa kimia metabolik sekunder. Steroid berasal dari perubahan asam asetat melalui mevalonat dan skualen (triterpenoid) menjadi lanosterol dan sikloartenol. Jenis dari steroid adalah Androsteron, Pregnan, Kolan, Kolestan, Ergostan, Stigmastan. Steroid mempunyai efek fisiologis yang mempengaruhi fungsi syaraf, jantung, dan hormonal [5]. Flavonoid merupakan senyawa fenolik yang berasal dari dua jalur biosintesis yaitu shikimat dan asetat malonat. Senyawa ini memiliki 15 atom karbon yang terikat pada 1 propana dan 2 molekul benzena [6]. Ghasemzadeh dan Ghasemzaneh juga menyebutkan bahwa flavonoid memberikan efek antioksidatif dan anticancer dan antiaging [7]. Alkaloid juga merupakan metabolik sekunder yang memiliki nitrogen dalam struktur kimianya. Menurut Facchini, alkaloid mempunyai efek analgesik, anticancer, stimulan dan relaksasi otot. asam karbaksilat, dan asam fosfat [8].

\section{METODE PENELITIAN}

Daun Ganyong merah dan putih diperoleh dari budi daya ganyong di daerah Pondok Kelapa Jakarta Timur, sedangkan umbi diperoleh dari Balai Penelitian Tanaman Kacang-Kacangan dan Umbiumbian (Balitkabi) Malang. Selanjutnya dilakukan pengujian terhadap kadar serat dan metabolit sekunder seperti alkaloid, steroid, flavonoid dan fenolik daun dan umbi Ganyong merah dan putih [9].

\section{Uji Serat Pangan}

Labu dan soxlet dikeringkan pada oven dengan suhu $105^{\circ} \mathrm{C}$ selama 60 menit lalu diletakkan pada kaki tiga. Sampel berupa simplisia dimasukkan pada pada soxlet dengan posisi labu di atas kaki tiga yang selanjutnya diisi dengan pelarut hexan dengan pemanasan yang menggunakan bunsen. Proses ini dilakukan selama 2 jam. Sampel yang diperoleh diambil 2,5 gram dan kemudian diletakkan di dalam cawan untuk dikeringkan pada oven $60^{\circ}$ C. Sampel yang telah bebas dari lemak tersebut diberikan H2SO4 1,25\% sebanyak $50 \mathrm{ml}$ dan dididihkan selama 30 menit. Proses selanjutnya adalah penambahan $50 \mathrm{ml} \mathrm{NaOH}$ $3.25 \%$ dan dididihkan selama 30 menit. Dalam kondisi panas larutan disaring dengan corong Buchner yang telah dilengkapi dengan kertas saring yang telah diketahui bobotnya. Endapan yang terbentuk pada kertas saring dicuci dengan $\mathrm{H} 2 \mathrm{SO} 4$ 1,25\%. Endapan yang terbentuk dimasukkan ke dalam cawan yang telah diketahui beratnya untuk selanjutnya dikeringkan pada suhu $105^{\circ} \mathrm{C}$ hingga berat tidak berubah.

Total Serat $($ Dietary Fiber $)(\%)=$ Sampel akhir/sampel awal x 100\% 


\section{Uji Alkaloid}

Uji alkaloid dilakukan dengan pereaksi Wagner yang terdiri atas $10 \mathrm{ml}$ aquadest ditambahkan 2,5 gram Iodin dan 2 gram Kalium Iodida. Selanjutnya simplisia daun dan umbi 1 gram dilarutkan dan diencerkan dengan aquadest menjadi $200 \mathrm{ml}$ dalam labu takar. Hasil sampel dinyatakan positif alkaloid jika dengan pereaksi Wagner terdapat endapan merah sampai jingga.

\section{Uji Steroid}

Sampel simplisia daun dan umbi 1 gram dimasukkan pada tabung reaksi selanjutnya direaksikan dengan $2 \mathrm{ml}$ kloroform, 10 tetes anhidrida asetat dan 3 tetes asam sulfat pekat. Hasil positif steroid jika terbentuk larutan berwarna merah yang kemudian berubah menjadi biru dan hijau.

\section{Uji Flavonoid}

Sampel simplisia daun dan umbi 1 gram ditambahkan serbuk magnesium 0,05 mg dan 0,2 alkohol yaitu berupa campuran asam klorida $37 \%$ dan etanol $95 \%$ dengan volume yang sama serta 2 $\mathrm{ml}$ alcohol. Hasil yang positif adanya flavonoid jika setelah pengocokan terbentuk warna merah, kuning, jingga .

\section{Uji Fenolik}

Sampel sebanyak 1 gram diekstrak dengan $20 \mathrm{ml}$ etanol $20 \%$ dan selanjutnya ditambahkan 2 tetes larutan $\mathrm{FeCl} 5 \%$. Hasil positif adanya senyawa fenolik jika tampak warna hijau atau hijau biru.

Hasil penelitian berupa data kuantitatif dan kualitatif yang diperoleh diolah dengan statistik deskriptif. Selanjutnya hasil penelitian disosialisasikan di masyarakat desa Sindanglengo Gunung Putri Jawa Barat.

\section{HASIL DAN PEMBAHASAN}

Pada satu rumpun Canna edulis Kerr berusia dua bulan dijumpai 3 tanaman dengan tinggi rata-rata $35.02 \mathrm{~cm}$, diameter batang $3.148 \mathrm{~cm}$, jumlah daun dalam tiap rumpun 16 denga lebar daun rata-rata $25,82 \mathrm{~cm}$. Berikut juga disajikan foto pengukuran dan penanaman Canna edulis Kerr yang akan dijadikan media sosialisasi pada waktu pengabdian masyarakat

Berdasarkan data prosentase serat ke dua jenis Ganyong lebih banyak dijumpai pada daun dibandingkan umbi (Tabel 1). Selain itu serat umbi putih lebih tinggi (3.40\%) dibandingkan umbi merah $(2.80 \%)$. Hal ini terjadi karena pada umbi terjadi lebih banyak penimbunan amilum. Kondisi ini membuka peluang dikembangkannya tepung dari Ganyong merah, akan tetapi umbi Ganyong putih lebih berpotensi sebangai alternatif makanan kesehatan karena kandungan seratnya yang lebih tinggi. Kandungan serat daun muda Ganyong merah lebih tinggi (26.20\%) dibandingkan Ganyong putih (24\%). Hal yang berbeda dengan daun tua dimana Ganyong putih lebih tinggi $(27.40 \%)$ dibandingkan dengan Ganyong merah $(25.60 \%)$.

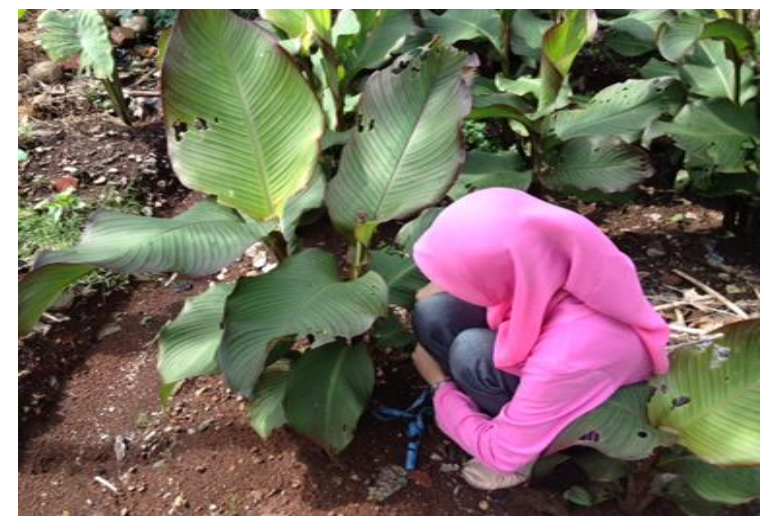

Gambar 1. Pengukuran anakan, batang, daun Canna edulis Kerr.

Tabel 1. Prosentase Serat pada Canna edulis Kerr. (Ganyong)

\begin{tabular}{llllc}
\hline No. & $\begin{array}{l}\text { Ganyong } \\
\text { Putih }\end{array}$ & $\begin{array}{l}\text { Serat } \\
(\boldsymbol{\%})\end{array}$ & $\begin{array}{l}\text { Ganyong } \\
\text { Merah }\end{array}$ & $\begin{array}{c}\text { Serat } \\
(\boldsymbol{\%})\end{array}$ \\
\hline 1. & daun muda & 24 & daun muda & 26,20 \\
2. & daun tua & 27,40 & daun tua & 25,60 \\
3. & umbi & 3.40 & umbi & 3,80 \\
\hline
\end{tabular}

Asupan serat berfungsi untuk mencegah penyakit jantung koroner, kanker usus besar, divertikular diabetes dan obesitas. Serat akan mengikat asam empedu hasil metabolisme kolesterol untuk selanjutnya dikeluarkan melalui feses. Dengan demikian penumpukan kolesterol yang dapat mengakibatkan arterosklerosis tidak terjadi. Kondisi arterosklerosis dapat memicu penyakit jantung koroner. Hasil metabolisme makanan yang dikonsumsi dapat berupa zat asing (zat karsinogenik). Zat tersebut dapat mempengaruhi ekosistem colon diantaranya menyebabkan peningkatan aktifitas mikroba dan selanjutnya memicu timbulnya kanker. Adanya serat yang cukup pada colon dapat menurunkan aktifitas mikroba, sehingga menurunkan resiko kanker colon. Serat juga mempengaruhi tekstur feses sehingga menurunkan tekanan kontraksi otot yang 
rendah ( $<10 \mathrm{mg} \mathrm{Hg}$ ) pada waktu buang air besar. Kontraksi otot yang tinggi setiap hari $>90 \mathrm{mg} \mathrm{Hg}$ dapat menyebabkan penonjolan usus berbentuk bisul yang diikuti dengan peradangan. Serat juga dapat mengurangi kegemukan karena dengan adanya serat dapat mengurangi penyerapan karbohirat, lemak dan protein [3] [4] [5]. Di samping itu serat juga dapat menyebabkan rasa kenyang dalam jangka waktu yang lama, dengan demikian dapat mengurangi resiko diabetes mellitus [10]. Asupan karbohidrat yang mengandung gula kompleks seperti dari umbiumbian dan sayuran dapat memperlambat biosintesis lemak. Selain serat kandungan metabolik sekunder juga mempunyai peranan dalam kesehatan seperti yang dikemukakan oleh [11]. Kandungan metabolik sekunder Canna edulis Kerr (Ganyong) disajikan pada Tabel 2.

Tabel 2. Kandungan Fitokimia Tanaman Ganyong

\begin{tabular}{lcccc}
\hline $\begin{array}{c}\text { Metabolik } \\
\text { Sekunder }\end{array}$ & \multicolumn{2}{c}{ Ganyong Putih } & \multicolumn{2}{c}{ Ganyong Merah } \\
Daun & Umbi & Daun & Umbi \\
\hline Alkaloid & - & + & - & + \\
Steroid & + & + & + & + \\
Flavonoid & + & + & + & + \\
Fenolik & + & + & + & + \\
\hline
\end{tabular}

Keterangan :

+ : terindikasi positif

- : tidak terindikasi

Hasil penelitian kandungan metabolik sekunder menunjukkan bahwa daun ganyong putih dan merah baik yang muda maupun yang tua tidak mengandung alkaloid, tetapi positif mengandung steroid, flavonoid dan fenolik. Adanya kandungan alkaloid dapat menyebabkan tanaman terasa pahit. Berdasarkan fakta bahwa tidak ditemukan adanya kandungan alkaloid maka daun Ganyong berpotensi untuk dijadikan alternatif sayur yang dapat dimakan sehari-hari. Kandungan fitokimia berupa alkaloid, steroid, flavonoid dan fenolik ditemukan pada umbi Ganyong merah dan putih (Tabel 2) . Fenolik merupakan antioksidan [12] yang dapat mencegah penyakit cancer, cardiovascular, arterosclerosis, hipertensi, diabetes dan penyakit neurogeneratif [13], demikian juga halnya dengan flavonoid menurut [7]. Alkaloid memiliki efek sebagai antidiabetic, anticarcinogenik, antibacterial [14]. Steroid berfungsi merupakan bioregulator dalam kehidupan organisme [15]. Hasil penelitian yang diperoleh selanjutnya disosialisasikan di masyarakat khususnya kaum ibu.

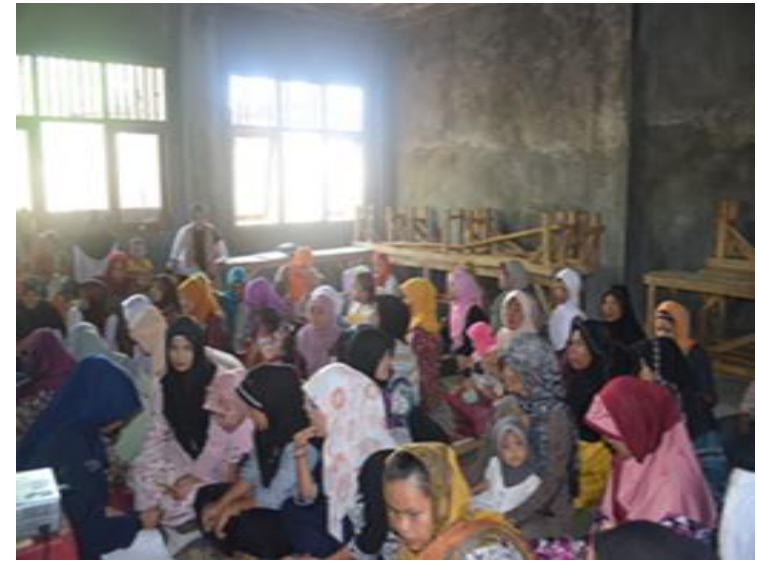

Gambar 2. Kegiatan Pengabdian Masyarakat di desa Sindanglengo Gunung Putri Jawa Barat

Hasil penelitian terhadap warga menunjukkan bahwa masyarakat desa Sindanglengo belum memahami masalah gizi yang meliputi tentang kekurangan dan kelebihan gizi, akan tetapi $82,5 \%$ masyarakat berusaha menyediakan makanan bergizi di rumah. Warga lebih banyak mengkonsumsi sayur dibandingkan sumber gizi yang berasal dari hewan. Sumber karbohidrat yang berasal dari umbi disajikan oleh $37,05 \%$ ibu rumah tangga disetiap minggu. Dengan demikian penyediaan serat pada bahan makanan untuk keluarga sudah memadai. Hal ini sejalan dengan hasil pengukuran gula darah yaitu prevalensi kelebihan gula darah sebesar $12,50 \%$ akan tetapi angka ini perlu diwaspadai .

Disamping itu juga ditunjukkan dengan kasus kanker yang rendah $(4,17 \%)$. Kontra indikasi terjadi ketika menghadapi kasus hipertensi sebesar 49.50\%. Hal ini dapat disebabkan oleh tingginya konsumsi garam oleh warga . Kasus hipotensi sebesar 50,50\% terjadi akibat kurangnya konsumsi hewani sebagai sumber protein keluarga.

Umumnya masyarakat telah mengenal tanaman ganyong (72.22\%) akan tetapi belum mengetahui produk olahan umbi ganyong. Masyarakat juga tidak memahami bahwa umbi ganyong dapat diolah ke dalam berbagai produk. Dengan demikian masyarakat belum mengetahui potensi umbi ganyong untuk dikembangkan menjadi berbagai produk olahan, demikian juga halnya dengan potensi daun ganyong yang mengandung kadar serat yang lebih tinggi dibandingkan umbinya. Masyarakat umumnya telah mengetahui bahwa pada beberapa tanaman berkhasiat untuk mengobati penyakit (75\%) [6]. Akan tetapi belum mengetahui potensi tanaman ganyong sebagai 
tanaman yang memberikan dampak positif terhadap kesehatan. Hal ini ditunjukkan dengan belum adanya upaya mengembangkan berbagai produk olahan umbi ganyong.

\section{KESIMPULAN}

Canna edulis Kerr yang terdiri atas ganyong merah dan putih mengandung serat tertinggi pada ganyong putih yaitu $27.40 \%$, pada daun tua, sedangkan ganyong merah terdapat di daun muda yaitu $26.20 \%$. Ganyong merah dan putih mengandung alkaloid, steroid, flavonoid, dan fenolik. Dengan demikian diperlukan sosialisasi yang intensif tentang manfaat ganyong bagi kesehatan.

\section{UCAPAN TERIMAKASIH}

Terimakasih kami sampaikan kepada Lembaga penelitian dan Pengabdian masyarakat LP2M Universitas Al Azhar Indonesia yang telah memberikan kesempatan dan dana Pengabdian Masyarakat berbasis Riset. Ucapan terimakasih juga kami sampaikan kepada semua mahasiswa yang ikut dalam penelitian maupun pengabdian masyarakat.

\section{DAFTAR PUSTAKA}

[1] H. Hadi, "Beban ganda masalah gizi dan implikasinya terhadap kebijakan pembangunan masyarakat," in Rapat Terbuka Majelis Guru Besar Universitas Gadjah Mada, Yogyakarta, 2005.

[2] W. D. Oktaviani, L. D. Saraswati and M. Z. Rahfiludin, "Hubungan kebiasaan konsumsi fast food, aktivitas fisik, pola konsumsi, karakteristik remaja, dan orang tua dengan indeks massa tubuh (IMT) studi kasus pada siswa SMA negeri 9 semarang," J. Kes. Masy. , vol. 1, no. 2, p. 542, 2012.

[3] S. Surbakti, "Asupan bahan makanan dan gizi bagi atlit renang," J. Ilmu Olah Raga, vol. 8, no. 2, pp. 108-122, Juli-Desember 2010.

[4] Departemen Pertanian, "Ganyong," 2010. [Online].
[5] S. Lenny, "Senyawa Terpenoid dan Steroid," 2004.

[6] S. Lenny, "Senyawa Flavonoid, Fenil propanoida, dan Alkaloida.," 2006.

[7] A. Ghasemzadeh and N. Ghasemzadeh, "Flavonoid and phenolic acid: role and biochemical activity in plant and human.," J. of Medicinal Plants Research, vol. 5, no. 31, pp. 6697-6703, 2011.

[8] P. J. Facchini, "Alkaloid biosynthesis in plant; biochemistry, cell biology, molecular, regulation, and metabolic engineering application," Аnпи. Rev. Plant Physiol. Plant Mol. Biol., vol. 52, pp. 29-66, 2001.

[9] A. T. Astuti, "Formulasi pembuatan dan pendugaan umur simpan beras aruk (beras singkong) dengan subtitusi kacang merah".

[10] H. Hutagalung, 2004. [Online]. Available: http://repository.usu.ac.id/bitstream/123456789/3 561/1/gizi-halomoan.pdf.

[11] R. Zamora-Ros, C. Andres-Lacueva, R. M. Lamuela-Raventos, T. Berenguer, P. Jaksyzn, A. Barricarte, E. Ardanaz, P. Amiano, M. Dorronsoro, N. Larranaga, C. Martinez, M. J. Sanchez, C. Navarro, M. D. Chirlaque, M. Z. Tormo, J. R. Quiros and C. A. Gonzales , "Estimation of dietary source and flavonoid intake spanish adult population (EPIC-Spain)," $J$. Of The American Dietetic Assosiation, vol. 110, no. 3, p. 390, 2010.

[12] N. S. Reddy, S. Navanesan, S. K. Siniah, N. Wahab and K. S. Sim, "Phenolic content, antioxidant effect and cytotoxic activity of Leea indica leaves," BMC Complementary \& Alternative Medicine, vol. 12, p. 128, 2012.

[13] M. Valko, D. Leibfritz, J. Moncol, M. T. Cronin, M. Mazur and J. Telser, "Free radical and antioxidants in normal physiological functions and human disease," Int J Biochem Cell Biol, vol. 39, no. 1, p. 44, 2007.

[14] M. Meghwal and T. K. Goswami, "A Review on the functional properties, nutritional content, medicinal utilization and potential application of fenugreek," J Food Process Technol, vol. 3, p. 181, 2012.

[15] V. Khripach, V. Zhabinskii and A. de Groot, "Twenty Years of Brassinosteroids: Steroidal Plant Hormones Warrant Better Crops for the XXI Century," Ann Bot, vol. 86, no. 3, pp. 441$447,2000$. 